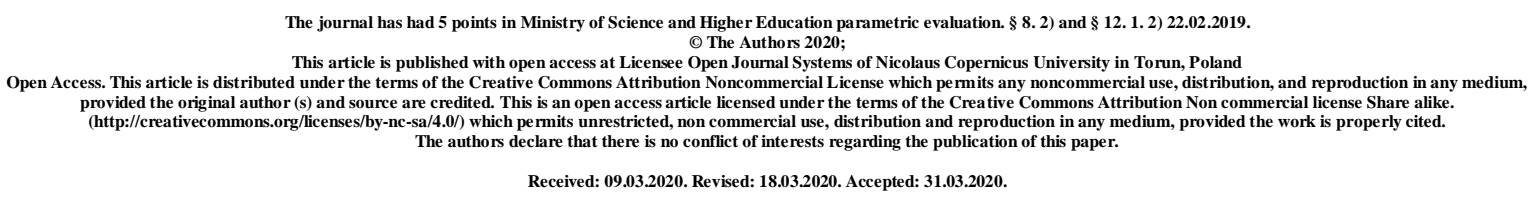

UDK 378.147

\title{
PREPARATION OF FUTURE GEOGRAPHY TEACHERS FOR PROFESSIONAL ACTIVITY ON A BASIS COMPETENCE APPROACH
}

\author{
Ihor Vasilievich Hevko
}

\section{Ternopil National Pedagogical University Volodymyr Hnatyuk}

\section{Abstract}

The professional competence of the future teacher of geography, in addition to the level of his own professional education, is determined by his motivated desire for continuous self-education and self-improvement, attitude to work.

The axiological component of the studied phenomenon is considered. If we understand professional training as a process of professional development, mastering the experience of future professional activity, we can say that a competent specialist is characterized by valuesemantic attitude to future activities. Positive attitude of future teachers to the emergence and development of professional pedagogical competence provides and supports motivational sphere. expressed in need and interest.

Preparation of future teachers of geography for professional activity has its own features, which allows to specify and clarify the definition of "preparation of future teachers of geography for professional activity" as an integrated education, including a system of organizational and pedagogical activities focused on educational process - obtaining professional knowledge and skills basics of methods of teaching geography as a pedagogical science and methods of its research, the formation of abilities and qualities necessary for future activities, and I result - the willingness of teachers to the profession. Accordingly, we can formulate a definition of "readiness of future geography teachers for professional 
activities" as an integral education that is manifested in the needs, desires, motives for professional activities, as well as provides the ability to educational activities based on existing geographical and pedagogical knowledge, skills and emotional experience. value attitude to geographical science.

Key words: competence; geography teacher; future specialist; educational process; readiness.

\title{
ПІДГОТОВКА МАЙБУТНІХ УЧИТЕЛІВ ГЕОГРАФІЇ ДО ПРОФЕСІЙНОӤ ДІЯЛЬНОСТІ НА ЗАСАДАХ КОМПЕТЕНТНІСНОГО ПІДХОДУ
}

\section{I. В. Гевко}

\section{Тернопільський національний педагогічний університет імені Володимира Гнатюка}

\begin{abstract}
Анотація
Професійна компетентність майбутнього вчителя географії, крім рівня власної професійної освіти, визначається його мотивованим прагненням до безперервної самоосвіти та самовдосконалення, ставленням до справи.

Розглянуто аксіологічний компонент досліджуваного феномена. Якщо розуміти професійну підготовку як процес професійного розвитку, оволодіння досвідом майбутньої професійної діяльності, то можна сказати, що компетентного фахівця характеризують ціннісно-смислове ставлення до майбутньої діяльності, Позитивне ставлення майбутнього вчителя до появи i розвитку професійно-педагогічної компетентності забезпечує і підтримує мотиваційна сфера, що виражається в потребі й інтересі.

Підготовка майбутніх учителів географії до професійної діяльності має свої особливості, що дозволяє конкретизувати та уточнити дефініцію «підготовка майбутніх учителів географії до професійної діяльності» як інтегральне утворення, що включає систему організаційно-педагогічних заходів зорієнтованих на освітній процес отримання професійних знань та вмінь, знання теоретичних основ методики

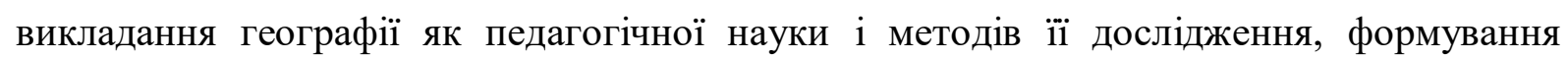
здібностей та якостей, необхідних у майбутній діяльності, та як результат - готовність майбутніх учителів до професійної діяльності. Відповідно можна сформулювати
\end{abstract}


дефініцію «готовність майбутніх учителів географії до професійної діяльності» як інтегральне утворення що виявляється в потребах, бажаннях, мотивах до професійної діяльності, а також забезпечує здатність до освітньої діяльності на основі сформованих географічних і педагогічних знань, умінь та навичок, досвіду емоційно-ціннісного ставлення до географічної науки.

Ключові слова: компетентність; учитель географії; майбутній фахівець; освітній процес; готовність.

Statement of the problem. The reference point of modernization of pedagogical education is the competence approach, which actualizes the need to study the phenomenon of "professional competence of a geography teacher". Given that this problem has been developed in science relatively recently, we note that there is still no consensus on this issue. Therefore, the understanding of professional competence of a teacher, necessary for the development of a strategy of competence-oriented teaching of geographical disciplines to students of future teachers of geography, is based on more general ideas about the competence model of the teacher. We investigated how the term "competence" is revealed in various sources:

- according to the Tuning project of the European Commission, it is a dynamic combination of knowledge, understanding, skills, values, other personal qualities that describe the learning outcomes of the educational / training program. Competencies are the basis of the graduate's qualifications. Competence (competencies) as the acquired realization abilities of a person to effective activity should not be confused with competence (competencies) as powers granted to a person [1];

- is a set of general and professional training that allows you to adequately respond to the needs of a particular job or work performed, which tend to change. It also depends on a person's attitude to their work, experience, diligence and ability to supplement their knowledge [2];

- the quality of personality that is necessary for quality productive activities in a particular area [3].

Analysis of recent research and publications. More precisely, in our opinion, the essence of the category "competence" is defined by Ukrainian scientists V. Yagupov and V. Svistun. They consider this concept as readiness for a certain professional activity and the presence of professionally important qualities of a specialist that contribute to this activity. According to their understanding, competence is manifested in activities and cannot be 
limited to certain knowledge, skills and abilities. Based on this, we can conclude that at the present stage of development of vocational education implementation of the competency approach is focused on the formation of the personality of the specialist - in the unity of his theoretical knowledge, practical training, ability and high motivation to carry out all professional and social activities.

Competence, which, in contrast to competence, involves a personal characteristic, attitude to the subject of activity is the result of the acquisition of competencies. Competence is formed from individual competencies, however, according to I. Gudzik, it is not identical with them [4]. In essence, the concept of "competence" is narrower, it correlates with specific activities as acquired realization abilities of the person. Interest in the problem of competence research arose in the late 60's of XX century. It was believed that the failure of specialists in various fields of economics is due to the incompetence of their teachers. The problem of forming competencies manifested itself in the following years in the process of developing a number of Western socio-pedagogical projects aimed at achieving the following results:

- improving the quality of training of specialists, their preparation for solving complex professional, social and technological problems that sometimes do not have an unambiguous solution;

- development of the most optimal testing system for students of different age groups;

- testing the professional skills of applicants with higher education who wish to obtain a teacher's certificate;

- testing of graduates of pedagogical faculties before assigning them certificates of teachers.

For the first time, the problem of competency research was scientifically substantiated at the conference "Competence: Analysis, Criticism, Reassessment" at the State University of Pennsylvania (USA, May 1980) [5].

Consider how modern researchers present the term "competence" in the educational context:

- alienated from the subject, a predetermined social norm (requirement) for the educational training of the student, necessary for his quality productive activity in a particular field, ie socially fixed result.

- powers granted (for example, by a normative legal act) to a person (another subject of activity), the scope of his (his) official and other rights and responsibilities;

- construction, which, unlike others, such as skills, abilities, qualifications, etc., determines the ability of a particular individual to self-organization. Competences are based 
on knowledge, constructed through values, as well as existing abilities, consolidated through experience, implemented on the basis of will;

- individuals have or acquired in the process of learning cognitive abilities and skills needed to solve specific problems, as well as related motivational, volitional and social readiness and abilities necessary to be able to successfully and responsibly solve problems in different situations;

- knowledge and skills that characterize the student's ability to perform, understand, reflect and know what is required by the educational and qualification characteristics of the specialist after the learning process. Competences are accompanied by clearly defined evaluation criteria [6].

Mastering key professional competencies is an important task of modern pedagogical theory and practice. The Key Competences for Europe document states that "competence is not limited to obtaining and using information, but also includes the ability and readiness for learning, research and retrieval, communication and collaboration, as well as the ability to adapt and readiness for professional development. practical activities "[7]. Based on this broad interpretation, competence can be defined as the ability to turn knowledge into experience and experience into activity; generalize and systematize knowledge; to organize one's own educational process, to be able to solve problems of different nature, to take responsibility for one's education; involves the formation of a number of significant skills and experience of their implementation: the ability to work with different sources of information, quickly learn and use information; ability to analyze, compare, establish the relationship between phenomena and processes, evaluate the phenomena of reality, works of art; ability to listen and speak, express their thoughts orally and in writing; ability to work in a team, cooperate, resolve conflicts, lead a monologue, dialogue and polylogue; ability to competently compile programs and projects of their professional activity, to take responsibility, to be able to organize. Analysis of the literature suggests considering the concept of "professional competence" as follows: a set of knowledge that determines the effectiveness of work; the amount of skills to perform the task; combination of personal qualities and properties; a set of knowledge and professionally significant personal qualities; vector of professionalization; unity of theoretical and practical readiness for work; ability to perform complex culturally appropriate actions, etc. Over the past 10 years, there have been studies on the development of professional competence of future teachers in a pedagogical university.

A significant number of studies have been devoted to the problem of the development of professional and pedagogical competence (E. Zeyer [8], I. Zymnya [9], I. Zyazyun [10], 
A. Markova [11], O. Pometun [12], etc.). The basis of professional and pedagogical competence, according to scientists, is the willingness to work as an integrative quality of personality.

The epistemological component of professional and pedagogical competence of future teachers involves adequate perception, understanding of natural and social processes of the real world (reflection, cognition, modeling).

Purpose of the research: Identify the features of training future teachers of geography for professional activities on the basiscompetency approach.

Basic material. the system of knowledge - many interconnected elements that represent a holistic education and are characterized by such qualities as flexibility, dynamism, variability, adaptability, predictability, heredity, integrity. Knowledge acts as a basis of professional and pedagogical competence of the teacher of any specialty and its preparation. The professional competence of a teacher is based on a system of general cultural, psychological, pedagogical and special knowledge.

The content of general cultural knowledge of a modern teacher is awareness in the field of the most significant achievements of mankind in various activities (science, art, religion, etc.), national and universal culture, spiritual and moral values, common cultural trends, in short, all that knowledge, based on which develops a cultural worldview of the teacher, creates conditions for his life and professional self-determination, forms a creative, spiritually rich personality. The modern specialist must know how to access global sources of knowledge, be able to transform the acquired knowledge into innovative technologies, have the knowledge required by the modern world [10].

The praxeological component of professional and pedagogical competence of future teachers consists of professional skills and abilities that a future geography teacher must possess in order to implement the functions of professional pedagogical activity and ensure its effectiveness. This component reflects the degree of practical readiness for professional pedagogical activity, includes not only professional skills and abilities, but also educational and life experience.

Coverage of the problem of pedagogical skills in the psychological and pedagogical literature is characterized by ambiguous positions of scientists on major issues, in particular on the grounds for classification of this phenomenon. Accordingly, the following main components proposed by modern researchers are distinguished:

- structure of components of pedagogical activity (N. Kuzmina [13]);

- functions of a teacher (I. Zyazyun [10], A. Shcherbakov [14], etc.); 
- differentiation of types of pedagogical skills (A. Markova [15])

The axiological component of professional and pedagogical competence of future teachers focuses on the subjective value position of the individual in the educational process. The axiological system of the individual is determined by his social relations and is based on a system of worldviews, ideas, value relations, value orientations.

Along with the epistemological, praxeological and axiological components of competence, the personal component of professional and pedagogical competence of future teachers should be considered. In this regard, M. Lukyanova notes: "... you can master professional skills only at the individual and creative level. Any psychological knowledge, before being embodied in pedagogical practice, is passed through the affective and value filters of personality, become the property of each teacher, turning into their own evaluative and conceptual categories, attitudes, behavioral programs. Such transformation of external (knowledge) into internal occurs at obligatory refraction of external influences through internal conditions (personal characteristics, qualities). It is professionally significant personal qualities that act as those internal conditions, passing through which external characteristics and requirements become the competence of the teacher "[13].

We will reveal the specifics of the epistemological component. Geographical knowledge is specific: it serves as a means of exploring the world, allowing you to see, understand and evaluate a complex system of relationships between people, territory and the environment. At the household level, a person with geographical knowledge can assess the prospects for a career transformation, where extract mineral raw materials in a reservoir, swamp - on pasture or arable land, etc.

In the process of studying geography in the minds of students formed a geographical picture of the world - a holistic image of the world, which has a historical character and fixes the main objects and relationships between them in the form in which they exist in modern geographical knowledge. In a broad sense, the geographical knowledge of the future teacher consists of several components:

- scientific perception of the world around;

- geographical (analytical) thinking related to the ability to determine causal relationships;

- spatial representations;

- the role of man and humanity in the development of world civilization.

The reason for the renewal of geography on the basis of a comprehensive country approach is the state of modern science, which, firstly, seeks to integrate its two branches 
(natural-geographical and socio-geographical) and, secondly, sees its goals in the study of fundamental laws of spatial organization. geographical shell, the interaction of nature and society.

Geographical competence presupposes the cartographic literacy of the teacher. Geographers have many special ways of describing, depicting, accumulating and summarizing information (verbal, written, graphic, statistical, cartographic). The concept of cartographic literacy includes cartographic thinking, a distinctive feature of such thinking is the attachment to the territory, the ability to think about the map, to use the map as a source of knowledge of the surrounding reality.

M. Baransky called the map the "second language" of geography, it is increasingly becoming the language of international communication. Formation of cartographic literacy is the most important element of professional training of a geography teacher. The development of the cartographic method of research in various fields of knowledge, the active introduction of GIS technologies significantly expand the range of users of the geographical map, which requires increasing the overall level of cartographic literacy of the population. The cartographic method in the cognition of reality is widely used not only by geographers but also by other specialists. Carl Ortwin Sauer notes: "Cards break our stiffness, stimulate our secretion, excite the imagination, loosen our tongues. The map has no language barriers, it acts as a language of geography "[16]. That is why the cartographic training of the future teacher of geography should be such a level of professional competence that will reproduce cartographic literacy of the general public.

Geography is a synthetic science that combines the lithosphere, atmosphere, hydrosphere, biosphere, technosphere - noosphere, which are a complex dialectical concept of the geographical shell. On the one hand, these are disciplines of the natural cycle, on the other - social.

The relationship of the whole system of special professional knowledge about the teacher of geography can be represented as follows:

- understanding the place of geography in the system of modern scientific knowledge and its significance; knowledge of the basics of the history of geography and the main directions of modern development;

- knowledge of fundamental ideas, laws, patterns that underlie school courses in geography;

- knowledge of basic geographical concepts; 
- knowledge of classical and modern methods, tools, techniques, technologies of professional activity in the specialty and position, the ability to apply, process, specify, develop. extract mineral raw materials in a reservoir, swamp - on pasture or arable land, etc.

In the process of studying geography in the minds of students formed a geographical picture of the world - a holistic image of the world, which has a historical character and fixes the main objects and relationships between them in the form in which they exist in modern geographical knowledge. In a broad sense, the geographical knowledge of the future teacher consists of several components:

- scientific perception of the world around;

- geographical (analytical) thinking related to the ability to determine causal relationships;

- spatial representations;

- the role of man and humanity in the development of world civilization.

The reason for the renewal of geography on the basis of a comprehensive country approach is the state of modern science, which, firstly, seeks to integrate its two branches (natural-geographical and socio-geographical) and, secondly, sees its goals in the study of fundamental laws of spatial organization. geographical shell, the interaction of nature and society.

Geographical competence presupposes the cartographic literacy of the teacher. Geographers have many special ways of describing, depicting, accumulating and summarizing information (verbal, written, graphic, statistical, cartographic). The concept of cartographic literacy includes cartographic thinking, a distinctive feature of such thinking is the attachment to the territory, the ability to think about the map, to use the map as a source of knowledge of the surrounding reality.

M. Baransky called the map the "second language" of geography, it is increasingly becoming the language of international communication. Formation of cartographic literacy is the most important element of professional training of a geography teacher. The development of the cartographic method of research in various fields of knowledge, the active introduction of GIS technologies significantly expand the range of users of the geographical map, which requires increasing the overall level of cartographic literacy of the population. The cartographic method in the cognition of reality is widely used not only by geographers but also by other specialists. Carl Ortwin Sauer notes: "Cards break our stiffness, stimulate our secretion, excite the imagination, loosen our tongues. The map has no language barriers, it acts as a language of geography "[16]. That is why the cartographic training of the future 
teacher of geography should be such a level of professional competence that will reproduce cartographic literacy of the general public.

Geography is a synthetic science that combines the lithosphere, atmosphere, hydrosphere, biosphere, technosphere - noosphere, which are a complex dialectical concept of the geographical shell. On the one hand, these are disciplines of the natural cycle, on the other - social.

The relationship of the whole system of special professional knowledge about the teacher of geography can be represented as follows:

- understanding the place of geography in the system of modern scientific knowledge and its significance; knowledge of the basics of the history of geography and the main directions of modern development;

- knowledge of fundamental ideas, laws, patterns that underlie school courses in geography;

- knowledge of basic geographical concepts;

- knowledge of classical and modern methods, tools, techniques, technologies of professional activity in the specialty and position, the ability to apply, process, specify, develop.

Indicators of the epistemological component are:

- literacy (humanitarian, natural science aspects of the initial knowledge of the world in harmony and interaction);

- education - is literacy, brought to the socially and personally necessary maximum. It presupposes the existence of a rather broad outlook on the most diverse issues of human life and society and a certain selectivity in the depth of understanding of the problems of the surrounding reality; education characterizes personal educational acquisitions.

The professional competence of the future teacher of geography, in addition to the level of his own professional education, is determined by his motivated desire for continuous self-education and self-improvement, attitude to work.

Consider the axiological component of the phenomenon under study. If we understand professional training as a process of professional development, mastering the experience of future professional activity, we can say that a competent specialist is characterized by valuesemantic attitude to future activities. Positive attitude of future teachers to the emergence and development of professional pedagogical competence provides and supports motivational sphere. expressed in need and interest. 
The trend of the last decade is an attempt to test the quality of those knowledge and skills that may be useful to graduates of free economic education in the future, as well as the ability to independently acquire the knowledge necessary for adaptation in today's world. Competence approach is able to combine the requirements of standard and life. It is necessary to assess the student's ability to solve problems posed to him by the educational environment within which they are.

Therefore, we will consider the praxeological component of the professional competence of the future teacher of geography through a system of pedagogical skills (in relation to the specialty). In this regard, we rely on the concept proposed by V. Vvedensky "intellectual and pedagogical competence which is expressed in the ability to apply existing knowledge to establish pedagogically appropriate relationships, acquisition and transformation of knowledge by students and the teacher, as well as to develop ways of innovation" [15].

The most vivid intellectual and pedagogical competence is manifested in professional activities, but it can not be equated with professionalism, it determines the degree of professionalism, characterized by a special type of organization of subject-specific knowledge and effective decision-making strategies - all responsible for the formation of future teachers gnostic skills. N. Kuzmina gives a convincing description of Gnostic skills: "Gnostic, or cognitive, research skills underlie all others and include the ability to analyze the pedagogical situation, formulate strategic, tactical and operational tasks in the field of education and training, develop strategies for their solution, evaluate productive and unproductive solutions and ways to implement them, re-formulate pedagogical tasks and look for more productive ways to solve them. For example, the ability to work with geographical and pedagogical literature, mastery of methods of pedagogical research, the ability to characterize the class and the student, objectively assess the knowledge, skills and abilities of students in physical and economic geography, geoecology, regional studies, etc.

In the structure of personal qualities of the teacher it is also necessary to allocate organizational abilities. General organizational skills were studied by L. Umansky, who identified 18 typical organizational qualities of the individual: the ability to "charge" other people with their energy; the ability to find the best use for each person; psychological selectivity; the ability to understand and respond correctly to human psychology; the ability to see the shortcomings in the actions of others - critical; psychological tact - the ability to establish the degree of influence; general level of development as an indicator of intelligence; initiative - creative and executive; demanding of other people; propensity for organizational 
activities; practicality - the ability to directly, quickly and flexibly apply knowledge and experience in solving practical problems; independence in contrast to suggestiveness and blind inheritance; observation; self-control, endurance; sociability; persistence; activity; efficiency; organization [15].

Thus, the professional competence of the future teacher of geography is an integrated ability of the individual, which ensures the readiness and success of teaching geography in secondary school at a high level.

Conclusion: preparation of future geography teachers for professional activity has its own features, which allows to specify and clarify the definition of "preparation of future geography teachers for professional activity" as an integrated education, including a system of organizational and pedagogical activities focused on educational process - professional knowledge and skills. knowledge of the theoretical foundations of methods of teaching geography as a pedagogical science and methods of its research, the formation of abilities and qualities necessary for future activities and, as a result, readiness.

\section{References:}

1. Educational glossary: higher education / edited by: II Babin, Ya. Ya. Bolyubash, AA Garmash and others. ; for order. DV Tabachnik, VG Kremenya. Kyiv: LLC "Ed. Pleiades House, 2011. 100 p.

2. Dmitrenko GA, Protasova NG Management of human resources: textbook. way. Kherson: Oldie-plus, 2006.

3. Moiseyuk NE Pedagogy: textbook. aid., 5th ed., ext. and processing. Kyiv, 2007. $656 \mathrm{p}$.

4. Yagupov VV, Svistun VI Competence approach to training in higher education. URL: www.libray.ukma.kiev.ua/e-llib/nz/nzv71_2007_pedagog/01_yagypov-w.pdf.

5. Short Edmund C. Competence: Analysis, Critique, ReassessTent. A Report of a Conference Held May 18-20, 1980, under the Auspices of the College of Education, the Pennsylvania State University, 55 p. URL: https://files.eric.ed.gov/fulltext/ED229337.pdf

6. Verbitsky AA, Larionava OG Personal and competence approaches in education: problems of integration. Moscow: Logos, 2013. 336 p.

7. George H. Mead. The Psychology of Social Consciousness Implied in Instruction. Science, 1910. 31. p. 88-93.

8. Zeer E. F. Theoretical and applied foundations of the psychology of professional development: a monograph. Ekaterinburg: Ros Publishing House. state prof.-ped. University, 2015. 194 p. 
9. Winter IA Socio-professional competence as a holistic result of professional education: (idealized model). Problems of quality of education. Competence approach in vocational education and design of educational standards. Moscow: Research. center of problems of quality of preparation of experts, 2005. S. 10-20.

10. Zyazyun IA Conceptual principles of the theory of education in Ukraine. Pedagogy and psychology of vocational education, 2000. № 1. P. 11-24.

11. Maksakovsky VP Geographical culture: a textbook for university students. Moscow: Vlados Humanitarian Publishing Center, 1998. 416 p.

12. Pometun OI Formation of civic competence: a view from the standpoint of modern pedagogical science. Bulletin of school exchange programs, 2005. № 23. P. 18-20.

13. Krylovets $\mathrm{MG}$ Professional and methodical training of future teachers of geography: theory and practice. Nizhyn: NDU Publishing House. M. Gogol, 2007. 301 p

14. Shcherbakov AI On the methodology and methods of studying the psychology of work and the teacher's personality. Psychology of personality and work of a teacher: Sat. scientific tr. under ed. AI Shcherbakova. L., 1976. Issue. 1. pp. 3-29.

15. Markova AK Psychological analysis of professional competence of the teacher. Covetskaya pedagogy, 1990. C. 8. P. 82-88.

16. Baransky NN What should be teaching in pedagogical institutes. Geography at school. 2004. №4. Pp. 37-40. 